\title{
Cykl prozatorski (cykl narracyjny, cykl opowiadań)
}

Termin teoretycznoliteracki, którym określa się zewnętrzne powiązania między opowiadaniami tworzącymi dany cykl. W Słowniku terminów literackich pod red. J. Sławińskiego pod hasłami dotyczącymi cyklu znajdziemy następujące definicje:

\begin{abstract}
Cykl nowelistyczny - odmiana cyklu literackiego: szereg nowel powiązanych w nadrzędną całość za pośrednictwem ramy kompozycyjnej, która je wszystkie ogarnia (np. Baśnie z tysiąca i jednej nocy, Dekameron G. Boccaccia), bądź za pomocą wspólnego elementu tematycznego (postaci lub motywu) występującego w każdym utworze (np. cykl nowelistyczny o Sherlocku Holmesie A. Conan Doyle’a, Trzynaście fajek I. Erenburga) czy poprzez jednolity punkt widzenia narratora wobec świata ukazywanego fragmentarycznie w kolejnych ogniwach cyklu (np. Ludzie stamtąd M. Dąbrowskiej), wreszcie poprzez problematykę ideową powtarzającą się we wszystkich utworach (np. Medaliony Z. Nałkowskiej). Forma cyklu nowelistycznego stanowiła w VIII w. jedno ze źródeł literackich powieści ${ }^{1}$.
\end{abstract}

Osobne hasło dotyczy cyklu literackiego:

Cykl literacki - zespół utworów należących do tego samego gatunku powiązanych w nadrzędną całość wspólnotą elementów treściowych (postaci literackiej, motywów, idei), bądź podobieństwem rozwiązań kompozycyjnych, ramą kompozycyjną, czy też jednością podmiotu literackiego. Każdy $\mathrm{z}$ utworów wchodzących w skład cyklu zachowuje zazwyczaj daleko posuniętą autonomię strukturalną i może być odbierany jako samodzielna całość; np. cykle średniowiecznych poematów rycerskich chansons de geste), cykl sonetów (Sonety krymskie Mickiewicza)2.

Powyższe definicje cyklu w wyraźny sposób akcentują konieczność zewnętrznego powiązania między opowiadaniami tworzącymi dany cykl (istnienie ramy kompozycyjnej oraz powiązań na poziomie świata przedstawionego), nawiązując w ten sposób do badań nad cyklicznością zapoczątkowanych przez formalistów rosyjskich w latach siedemdziesiątych ubiegłego wieku. Inne spojrzenie na definicję cyklu narracyjnego proponują badacze amerykańscy, dla których elementem niezbędnym jest „konieczność zaistnienia między opowiadaniami szczególnego związku o charakterze semantycznym”3. F.L. Ingram w książce Representative Short Story Cycles of Twentieth Century cyklem nazywał „książkę składającą się z opowiadań połączonych przez autora w taki sposób, że czytelnik sukcesywnie rozpoznaje deseń (wzór, model) całości na różnych poziomach lektury, co w znacznej mierze modyfikuje odbiór jego części

\footnotetext{
${ }^{1}$ Hasło Cykl nowelistyczny, J. Sławiński, [w:] Słownik terminów literackich, red. J. Sławiński, wyd. II, Wrocław 1989, s. 79.

${ }^{2}$ Hasło cykl literacki, J. Sławiński, [w:] Słownik terminów literackich, red. J. Sławiński, wyd. II, Wrocław 1989, s. 64.

${ }^{3}$ K. Jakowska, O cyklu opowiadań. Z teorii i historii cyklu narracyjnego w Polsce, Białystok 2011, s. 13.
} 
składowych"4. Terminy te Krystyna Jakowska, jedna z najbardziej znanych badaczek cykliczności, uważa za niepełne, dlatego proponuje swoją definicję cyklu narracyjnego, nazywając nim: „zbiór różnorodnych opowiadań, z których każde stanowi skończoną całość, wszystkie jednak są ze sobą związane. Dzięki temu związaniu całość cyklu stanowi wobec każdego z opowiadań całość nadrzędną - semantyczną i kompozycyjną. Każde zatem opowiadanie przez swoją przynależność do cyklu modyfikuje swoje znaczenie - znaczy inaczej i więcej niż wtedy, gdy czytamy je w izolacji”".

Badania nad cyklem narracyjnym stały się obiektem zainteresowania polskich badaczy literatury dość późno, bo dopiero w latach dziewięćdziesiątych XX wieku. O wiele szybciej zainteresowano się jednak w Polsce teorią cyklu lirycznego. Najbardziej znaną pracą jest tekst Wiesławy Wantuch O poetyce cyklu lirycznego, w którym autorka nie tylko definiuje pojęcie cyklu lirycznego na gruncie polskim, ale także za pomocą odpowiednich przykładów prezentuje trzy podstawowe rodzaje cyklów literackich. Dla Wantuch

Cykl liryczny to kompozycja rozpięta między dwoma biegunami: dążeniami do zamknięcia, ujawnienia specyficznych właściwości struktury, która nie jest sumą składników, a autonomią poszczególnych utworów w jej skład wchodzących. W zależności od tego, które z tendencji przeważają, można wymienić trzy główne typy układów cyklicznych: koncentryczny, łańcuchowy i pierścieniowy ${ }^{6}$.

Zdaniem badaczki najsilniej zdeterminowany jest pierwszy z nich, którego doskonałym przykładem jest tak zwany „wieniec sonetów (soneti di corona)”, wszystkie utwory wchodzące w jego skład łączy nie tylko jedność tematu, ale także stała liczba: 1+14. Dodatkowo początek każdego sonetu stanowi kolejny wers otwierającego kompozycję utworu. Nie można więc zmienić ich kolejności, ponieważ podważyłoby to kunsztowność układu. Jako przykład Wantuch wymienia Poezje zebrane Antoniego Słonimskiego. Kompozycja tych utworów zorganizowana jest wokół centrum, które stanowi - gatunek, temat, słownictwo i podmiot liryczny pierwszego sonetu. Kolejnym przykładem literackim są Sonety krymskie Mickiewicza, których kompozycja zorganizowana jest w zupełnie inny sposób. Możemy wyróżnić wśród nich takie grupy jak: „sonety stepowe” (Widok gór ze stepów Kozłowa), „morskie” (Cisza morska, Żegluga, Burza) czy „górskie”. Występują tutaj sonety-wyznania, oraz sonety-rozmowy Pielgrzyma z Mirzą, sonety cytujące Mirzę czy sonety opisowe.

Kompozycja Sonetów krymskich daje się porównać z kunsztownym łańcuchem, którego każde ogniwo, niezbyt podobne do poprzedniego czy następnego, niewątpliwie przynależy do splotu i wydłuża go [...]. Cykl Mickiewicza nie wspiera się na tak łatwo wykrywalnych i regularnie stosowanych spojeniach. O jego ciągłości stanowi zasadniczo organizacja ponadsłownikowa, pozagatunkowa ${ }^{7}$.

\footnotetext{
${ }^{4}$ Cyt. i tłum. za tamże, s. 12.

${ }^{5}$ Tamże, s. 25.

${ }^{6}$ W. Wantuch, O poetyce cyklu lirycznego, [w:] Miejsca wspólne. Szkice o komunikacji literackiej i artystycznej, red. E. Balcerzan, S. Wysłouch, Warszawa 1985, s. 43.

7 Tamże, s. 47.
} 
Trzeci rodzaj cyklu poetyckiego - pierścieniowy - reprezentują Postacie Bolesława Leśmiana. „Cykl Leśmianowski, w porównaniu z poprzednimi wydaje się najmniej spójny. Wchodzące w jego skład utwory różnią się pod względem rozmiaru, wzorców rymowych i słownictwa [...]. Jedynie wyraźnie "pierścieniowy» charakter wierszy otwierających i zamykających pozwala odnaleźć jednego nadawcę i wykryć zasadę, na podstawie której można przypisać mu wszystkie teksty".

Wantuch w swojej analizie cykliczności utworów lirycznych odwołuje się nie tylko do poszczególnych przykładów, ale też do ogólnych tez dotyczących utworów literackich zebranych w cykle. Badaczka szczególną uwagę zwraca na konieczność zaistnienia w cyklu warunków spójności określonych przez Marię Renatę Mayenową:

Tekst spójny musi spełniać następujące warunki: 1) musi być tworem jednego nadawcy, tj. każde „chcę”, „wiem”, „czuję”, „sądzę" w ramach modalnych wszystkich zdań tekstu winno mieć „ja” odnoszące się do tej samej osoby lub tej samej grupy osób; 2) musi mieć tego samego odbiorcę, tj. wszystkie „ty” możliwych ram modalnych winny odnosić się do tej samej osoby lub tej samej grupy osób; 3) i wreszcie musi mieć ten sam temat ${ }^{9}$.

Drugim istotnym elementem jest podkreślenie konieczności obecności czytelnika aktywnego, który w zależności od układu utworów tworzących dany cykl musi jedynie rozpoznać zasadę cykliczności lub też posłużyć się swoją szerszą wiedzą na temat informacji metatekstowych zawartych $\mathrm{w}$ danym tekście literackim, by poprawnie odczytać informacje w nim zawarte.

O wiele bardziej skomplikowana jest próba usystematyzowania pojęcia cykliczności w odniesieniu do prozy. Jak zaznacza Bogumiła Kaniewska, cykl powieściowy „należy do form gatunkowo «niepewnych» - jest jednocześnie całością i zbiorem całostek, tekstem i szeregiem tekstów, podwójnie delimitowanym"10. Wielu badaczy traktuje cykl jako zjawisko wyłącznie kompozycyjne. Jan Trzynadlowski w tekście Kompozycja cyklu literackiego definiuje poetykę cyklu „jako system rygorów wyznaczających kompozycję utworów występujących wyraźnie jako zespół, jako całość złożoną z organizmów podporządkowanych"11, z kolei niemiecki badacz - Rolf Fieguth - uznaje cykl za gatunek pochodny, mówiąc, że „mimo szerokiego spektrum wariacji, które pojawiły się w trakcie jego [cyklu - P.M.] rewolucji, wykazuje zadziwiająco trwałe właściwości gatunkowe"12.

Krystyna Jakowska zauważa, że powiązania utworów wchodzących w skład cyklu realizują się na wielu poziomach. Może łączyć je na poziomie zewnętrznym: wyraźna rama kompozycyj-

\footnotetext{
${ }^{8}$ Tamże, s. 48-49.

${ }_{9}^{9}$ M.R. Mayenowa, Poetyka teoretyczna, Wrocław 1978, s. 256.

${ }^{10}$ B. Kaniewska, Między cyklem a powieściq, s. 23-35

${ }^{11} \mathrm{~J}$. Trzynadlowski, Kompozycja cyklu literackiego, „Acta Universitatis Wratislaviensis. Prace literackie IX”, nr 67, Wrocław 1967.

${ }^{12} \mathrm{R}$. Fieguth, Rozpierzchłe gałazki. Cykliczne i skojarzeniowe formy kompozycyjne w twórczości Adama Mickiewicza, przeł. M. Zieliński, Warszawa 2001, s. 28.
} 
na, postawa narratora, problematyka, temat, wybór bohatera, świat przedstawiony ${ }^{13}$. Na poziomie "tekstowym i metatekstowym”, czyli wewnętrznym: scalające tytuły, motta, początki, końce, „deliminacja cyklu” oraz linearne uporządkowanie opowiadań ${ }^{14}$. Rekonstrukcja sensu globalnego całego cyklu możliwa jest jedynie w procesie lektury linearnie zestawionych opowiadań.

Rekonstruując dzieje cyklu narracyjnego w Polsce, Jakowska wyróżnia kilka podstawowych rodzajów cykli narracyjnych: historyczne, portretowe, autobiograficzne, „filozoficzne” lub problemowe oraz ,intertekstualne”. Pierwsze z nich, tak jak wskazuje nazwa, ogniskowały wokół wydarzeń historycznych - powstania styczniowego (E. Orzeszkowa, Gloria victis, A. Strug, Ojcowie nasi), popowstaniowych represji (W. Sieroszewski, W matni. Nowele jakuckie, A. Szymański, Szkice), rewolucji 1905 roku (A. Niemojewski, Ludzie rewolucji, A. Strug, Ludzie podziemni, E. Słoński, $W$ więzieniu), I wojny światowej i wojny polsko-rosyjskiej 1920 roku (J. Kaden-Bandrowski, Mogity, Z. Kisielewski, Krwawe drogi, Z. Nałkowska, Tajemnice krwi, W.S. Reymont, Za frontem, K. Wierzyński, Granice świata), II wojny światowej (Z. Nałkowska, Medaliony, W. Solski, Opowieść o Szwejku, K. Wierzyński, Pobojowisko) - a zwłaszcza tematyki: obozów niemieckich (T. Borowski, Kamienny świat, J. Andrzejewski, Noc), sowieckich łagrów (H. Naglerowa, Kazachstańskie noce, P. Bednarski, Błękitne śniegi), Katynia (W. Odojewski, Zabezpieczanie śladów, J. Trznadel, $Z$ popiołów czy wstaniesz? Opowiadania „stamtąd”). Liczna grupa cykli dotyczy także tematyki holocaustu (A. Sandauer, Śmierć liberała, J. Mauer, Liga ocalałych, K. Żywulska, Pusta woda) oraz stanu wojennego (J. Anderman, Brak tchu, D. Terakowska, Guma do żucia). Fragmentaryczna forma opowiadań idealnie wpisywała się w charakter opisywanych doświadczeń, ukazując ich nielinearność.

Kolejna wymieniona przez Jakowską grupa cykli - cykle portretowe - badaczka podzieliła na "charaktery", "galerie”, cykle portretów naturalistycznych i portrety realistyczne. Tak zwane "charaktery” to tworzone już w starożytności „ciągi zbiorów małych form narracyjnych [...] pozbawione z reguły wyrazistego końca" ${ }^{15}$, które sytuują się na pograniczu cyklu i serii. Charaktery dawniej wyróżniały się tematyką satyryczną, jednak w XX wieku idealnie sprawdziły się także w tematyce psychologicznej i społecznej (Charaktery Zofii Nałkowskiej) czy nawet wojennej (Charaktery dawne i ostatnie także Nałkowskiej). „Galerie” z kolei to obrazki, szkice fizjologiczne układane w zbiory. Ich inna nazwa to „albumy”. Miały charakter satyryczny (A. Niewiarowski, Galeria panien na wydaniu) lub nostalgiczny (M. Bałucki, Typy i obrazki krakowskie). Cykle portretów powstawały pod koniec XIX i na początku XX wieku, najczęściej tworzyły je opowiadania lub nowele. Podejmowana przez twórców cykli portretów tematyka dotyczyła najczęściej problematyki zła. Wśród najbardziej znanych warto wymienić - One G. Zapolskiej oraz Zawody J. Kadena-Bandrowskiego. Ostatni typ cykli portretowych to portrety realistyczne, tworzone pod koniec XIX wieku (M. Konopnicka, Moi znajomi, E. Orzeszkowa, Melancholicy), w latach międzywojennych (M. Dąbrowska, Ludzie stamtąd, M. Kuncewiczowa, Dwa księżyce, H. Boguszewska, Ci ludzie), rzadziej współcześnie. Portrety realistyczne ukazywały postaci zindywidualizowane, zanurzone $\mathrm{w}$ wydarzeniach i realiach swego czasu. Boha-

\footnotetext{
${ }^{13} \mathrm{~K}$. Jakowska, O cyklu opowiadań..., s. 25.

${ }^{14}$ Tamże, s. 13.

${ }^{15}$ Tamże, s. 40.
} 
terów często zestawiano ze sobą na zasadzie kontrastu - wybierając osoby pochodzące z różnych środowisk, reprezentujące odmienne poglądy.

Trzecią grupę stanowią cykle autobiograficzne, które „odwzorowują cykl życia narratora-bohatera-autora, tworząc rodzaj ujętej w cykl opowiadań powieści rozwojowej”16. Gatunek ten wykrystalizował się z autobiograficznych pasji pisarzy dwudziestolecia międzywojennego. Lata dwudzieste i trzydzieste XX wieku bogate są w cykle obrazujące proces dorastania młodych ludzi żyjących w czasach niewoli - J. Kaden-Bandrowski, Miasto mojej matki, M. Dąbrowska, Uśmiech dziecinstwa. Cykle z lat osiemdziesiątych i dziewięćdziesiątych XX wieku ukazują życie młodych ludzi dorastających w czasach PRL-u - K. Nowicki, Drugie życie, M. Nowakowski, Portret artysty z czasów dojrzałości.

Czwartą grupę stanowią cykle filozoficzne, czy też cykle problemowe, które poruszają najczęściej tematykę psychologiczną i społeczną. Ich rodowód sięga starożytności. W wieku XX wyrażały one najczęściej tezę o dysharmonii świata - A. Wat, Bezrobotny Lucyfer, W. Gombrowicz, Pamiętnik z okresu dojrzewania, E. Stachura, Jeden dzień. Ostatnią grupę stanowią cykle intertekstualne bazujące na innym tekście literackim - modlitwie (G. Zapolska, Modlitwa pańska), katechizmie (R. Tomczyk, Uczynki miłosierne), czy też na wzorze instytucji małżeńskiej (Z. Nałkowska, Małżeństwo). Dialog z pierwotnym tekstem, na którym bazuje cykl interseksualny, powoduje multiplikację znaczeń i pozwala odczytać dodatkowe sensy.

Według badaczki dla historii badań na cyklem literackim w Polsce niezwykle ważne jest prześledzenie historii ramy cyklu, czyli „najbardziej widocznego, zewnętrznego czynnika scalającego cykl opowiadań". W staropolskich reprezentacjach cyklu rama miała charakter wyraźnie narracyjny - posiadała własną fabułę, w którą wtopiony był cykl. Narracyjną całość starano się budować jeszcze w XVIII, a nawet na początku XIX wieku. Z biegiem czasu fabularność ulegała zubożeniu, jednak w cyklu opowiadań do obowiązków autora należy „stworzenie postaci opowiadającej i rozbudowanie sytuacji opowiadania; ujawnianie, gdzie się opowiada i kto słucha"17. W drugiej połowie XIX wieku cykle powieściowe nie posiadają już samodzielnej, zawierającej własną fabułę ramy narracyjnej. Zmienia ona swój ton na "gawędowy" - jest najczęściej pierwszoosobowa, autorska, przeplata żartobliwość z moralizatorskim tonem „na serio", jest autotematyczna i swobodna w kompozycji.

Kolejna zmiana nastąpiła w cyklach naturalistycznych - tam gawędowość zastąpiono, zwłaszcza w młodopolskich utworach, ramą podmiotową i poetycko nacechowaną. W opowiadaniach dwudziestowiecznych ramę zastępują inne sposoby wiązania fabuły utworów budujących cykl. Wśród nich Jakowska wymienia: „chronologiczny układ zdarzeń, grę tytułami, cytat z wstępnej części tekstu w zakończeniu, układ logiczny lub odpowiedniość wobec zewnętrznego tekstu wzoru"18. Opowiadania dotyczące czasu II wojny światowej wyróżniają się powrotem ramy, prawdopodobnie ze względu na potrzebę uwiarygodnienia opisywanych wydarzeń. Podobne wzmocnienie ramy widoczne jest $\mathrm{w}$ opowiadaniach $\mathrm{z}$ lat

\footnotetext{
${ }^{16} \mathrm{~K}$. Jakowska, Cykl opowiadań próba historii. Intuicje i sugestie, [w:] Cykl literacki w Polsce, red. K. Jakowska, B.

Olech, K. Sokołowska, Białystok 2001, s. 43.

${ }^{17}$ Tamże, s. 44.

${ }^{18}$ Tamże, s. 45.
} 
osiemdziesiątych i dziewięćdziesiątych XX wieku. W Murach Hebronu Stasiuka ostatnie opowiadanie nawiązuje wprost do pierwszego. Cykl L. Elektrowicza otwiera „Prolog”, zamyka „Epilog”, w czym Jakowska dopatruje potrzeby współczesnych pisarzy do uspójnienia ram cyklu opowiadań.

Patrycja Malicka 


\section{SŁOWA KLUCZOWE:}

cykl liryczny

C Y K L P O E T Y C K I

cykl

cykliczność

cykl portretowy,

u k ład pierścieniowy

cykl literacki

cykl intertekstualny

\section{AbstrakT:}

Hasło ukazuje powiązania i różnice występujące pomiędzy takimi określeniami, jak cykl literacki, cykl nowelistyczny czy cykl poetycki w kontekście cyklu prozatorskiego, a także obrazuje stan badań nad zagadnieniem w Polsce. Choć badania nad zagadnieniem cykliczności interesowały już formalistów rosyjskich, tematyka ta spotkała się z zainteresowaniem w naszym kraju dopiero w latach dziewięćdziesiątych ubiegłego wieku, głównie za sprawą badaczy z Wydziału Filologicznego Uniwersytetu w Białymstoku. Tekst podejmuje próbę usystematyzowania pojęcia cykliczności w odniesieniu do prozy na podstawie prac Krystyny Jakowskiej, Bogumiły Kaniewskiej, Jana Trzynadlowskiego i Rolfa Fiegutha. 


\title{
cykl proza
}

\section{układ łańcuchowy}

cykl autobiograficzny

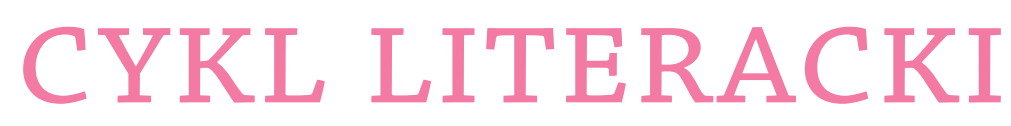

cykl historyczny

\author{
układycykliczne \\ układ koncentryczny
}

CYKL NOWELISTYCZNY

\section{NOTA O AUTORZE:}

Patrycja Malicka - doktorantka w Zakładzie Literatury XX Wieku, Teorii Literatury i Sztuki Przekładu na Wydziale Filologii Polskiej i Klasycznej Uniwersytetu im. Adama Mickiewicza w Poznaniu. W kręgu jej zainteresowań badawczych znajdują się takie zagadnienia, jak: recepcja romantyzmu w polskiej literaturze najnowszej, teoria afektu, kategoria nastroju (Stimmung). 